\title{
Mechanism of Leaf Vein Coloration and Inheritance of Leaf Vein Color, Flower Form, and Floral Symmetry in Gloxinia
}

\author{
Pei-Wen Kan, Yu-Ching Cheng, and Der-Ming Yeh \\ Department of Horticulture and Landscape Architecture, National Taiwan University, No. 1, \\ Section 4, Roosevelt Road, Taipei 10617, Taiwan
}

\begin{abstract}
AdDitional INDEX words. air space, breeding, double flower, Sinningia speciosa, structural variegation
Abstract. Double-flowered gloxinia (Sinningia speciosa) cultivars with foliar variegation might have a greater market appeal as flowering foliage plants. Crosses were made among 16 gloxinia cultivars and their progenies were analyzed to determine the inheritance of leaf vein color, flower form, and floral symmetry. All plants from self-pollinating white-veined cultivars or crosses between white-veined and green-veined cultivars produced white veins. Progeny derived from self-pollinating plants of white-veined cultivars $\times$ green-veined cultivars segregated into a ratio of 3 whiteveined:1 green-veined. All plants from self-pollinating or cross-pollinating single-flowered cultivars produced single flowers. Progeny of self-pollination or crosses between double-flowered cultivars segregated into a ratio of 3 double flowers: 1 single flower. Contingency chi-square tests revealed that leaf vein color and flower form were inherited independently. New gloxinia progenies with homozygous white veins and double flowers were successfully developed from the $F_{2}$ segregating population. Plants from self-pollinating or cross-pollinating cultivars with actinomorphic flowers produced actinomorphic flowers. A single dominant gene expressed in the homozygous or heterozygous state resulted in the zygomorphic flowers. Independent inheritance was observed between vein color and floral symmetry. Air spaces between the epidermis and the mesophyll cells were observed in the white, but not in the green, leaf vein portions. Net photosynthesis did not differ significantly between the white vein and adjacent green portion of the same leaf.
\end{abstract}

Florist gloxinia (Sinningia speciosa) is native to Brazil within the family Gesneriaceae. Gloxinia is a popular flowering potted plant grown for its fleshy, velvety leaves and large colorful flowers with various symmetries and forms. The wholesale value of potted gloxinia reached $\$ 500,000$ in 2009 and 2014 (U.S. Department of Agriculture, 2021).

Depending on the cultivar, gloxinia have zygomorphic or actinomorphic flowers (Zaitlin, 2012). Actinomorphic floral symmetry is controlled by a recessive allele $(c c)$, whereas a single dominant gene expressed in the homozygous $(C C)$ or heterozygous $(C c)$ state results in zygomorphic floral symmetry (Hsu et al., 2017). The flower form is controlled by one single nuclear locus with two alleles, and that double flower is dominant over single flowers. The double-flowered heterozygote occasionally has markedly fewer petals than the double-flowered homozygote of gloxinia (Clayberg, 1975; Shalit, 2000). Double-flowered gloxinia cultivars with white leaf veins are commercially desirable but are currently rare.

Inheritance of foliar variegation has been studied in several genera of foliage plants such as aglaonema (Aglaonema sp.), caladium (Caladium sp.), and dieffenbachia (Dieffenbachia sp.), but not in the Gesneriaceae family. The presence of foliar variegation in aglaonema and dieffenbachia is dominant in nonvariegation (Henny and Chen, 2010). Inheritance of the white foliar midrib is controlled by a single dominant nuclear gene in three

Received for publication 15 Dec. 2020. Accepted for publication 17 Feb. 2021.

Published online 20 April 2021.

This paper is a portion of a MS thesis submitted by P.-W.K

We gratefully acknowledge the financial support from the Ministry of Science and Technology, Taiwan (108-2313-B-002-054-MY3).

D.-M.Y. is the corresponding author. E-mail: dmyeh@ntu.edu.tw.

This is an open access article distributed under the CC BY-NC-ND license (https://creativecommons.org/licenses/by-nc-nd/4.0/). dieffenbachia cultivars (Henny, 1983). A single dominant allele determines the presence of silver-grey stripes overlaying the leaf veins in aglaonema cultivars (Henny, 1986). A single locus with three alleles determines the main vein color in caladium cultivars. The locus has been designated as $V$ and the order of dominance is $V^{\mathrm{t}}$ (red vein) $>V^{\mathrm{W}}$ (white vein) $>V^{\mathrm{g}}$ (green vein) (Deng and Harbaugh, 2006). No information regarding the inheritance of the white vein in gloxinia is currently available.

Four mechanisms of foliar variegation have been identified by Hara (1957), namely, chlorophyll type, pigment type, air space type, and epidermis type. Most foliar variegation can be characterized into two basic categories. True variegation is demonstrated by leaves with areas of little or no chlorophyll (Aluru et al., 2001; Wang et al., 2018) or pigmentation (Hughes et al., 2014; Pao et al., 2020). Other types of variegation are caused in part, by anatomical features such as trichomes, scales, or air spaces between the upper epidermis and mesophyll cells (Sheue et al., 2012). Leaf coloration and variegation may alter photosynthetic efficiency. The variegation of Aglaonema nitidum 'Curtisii' is caused by the presence of air spaces, and such variegation is unavailable for photosynthesis (Fooshee and Henny, 1990). In contrast, the maximum quantum yield of photosystem II, as measured by $\mathrm{Fv} / \mathrm{Fm}$, does not differ significantly between the light and green areas in the air space type of variegated begonia such as $B$. formosana, $B$. diadema, and B. pustulata (Sheue et al., 2012). The mechanism of the white vein and comparative photosynthesis between the white and green leaf portions of gloxinia remain unclear.

The objectives of this study were to 1) understand the inheritance of vein color, flower form, and floral symmetry in our population, and to determine if the vein color character is linked with the flower form or floral symmetry; 2) develop new gloxinia progeny with white veins and double flowers; and 3) compare the anatomy and photosynthesis of the white and green leaf portions. 


\section{Materials and Methods}

Plant materials. Commercial cultivars were used as parents in various crosses. Fourteen $\mathrm{F}_{1}$ cultivars (Avanti Blue, Avanti Light Violet/Dark Throat, Avanti Peach Rose, Avanti Red with White Edge, Avanti Scarlet, Brocade Purple, Brocade Purple/ White Bicolour, Brocade Red, Brocade Red/White Bicolour, Empress Purple Spotted Throat, Espirito Santo, MultiBells Blue, MultiBells Cherry, and MultiBell White) have green veins and two cultivars (SS and Diego Pink) have white veins. Brocade cultivars are double-flowered, and the other cultivars produce single flowers. Plants of cultivars Avanti, Brocade, and Empress Purple Spotted Throat produce actinomorphic flowers, whereas the other cultivars have zygomorphic flowers.

All the plants were raised from seeds, and young seedlings with two pairs of leaves were transplanted to 9-cm pots containing a 1:1 ratio of peatmoss (Fafard No. 1; Conrad Fafard, Agawarm, MA) and vermiculite (by volume). Plants were fertilized weekly with water-soluble $20 \mathrm{~N}-8.7 \mathrm{P}-16.6 \mathrm{~K}$ fertilizer $(20-20-20$ General Purpose; JR Peters, Allentown, PA) at $1 \mathrm{~g} \cdot \mathrm{L}^{-1}$ and irrigated as needed. Plant raising, pollination, and evaluation were conducted in a shaded greenhouse with an average noontime photosynthetic photon flux of $1011 \mu \mathrm{mol} \cdot \mathrm{m}^{-2} \cdot \mathrm{s}^{-1}$ and mean daily temperature of $27^{\circ} \mathrm{C}$. Emasculation and pollination were conducted following the method described by Shalit (2000).

INHERITANCE OF VEIN COLOR, FLOWER FORM, AND FLORAL SYMMETRY. The white-veined 'SS' and green-veined cultivars were self-pollinated and cross-pollinated. Progeny from ' $\mathrm{SS}$ ' $\times$ 'Brocade Red/White Bicolour' and 'Diego Pink' $\times$ 'MultiBells
Blue' were generated by selfing. Vein color, flower form, and floral symmetry (Fig. 1) were recorded when the plants had two open flowers. Single-flowered plants were categorized as normal. Double-flowered plants were categorized as possessing more than two whorls of petals. Data were subjected to the chi-square test for goodness of fit to compare actual ratios with expected ratio.

STRUCTURAL DIFFERENCES AND PHOTOSYNTHETIC MEASUREMENTS. Lateral vein areas of the fully expanded leaves (leaf 2 from the apex) of plants derived from $\mathrm{F}_{2}$ generation of ' $\mathrm{SS}$ ' $\times$ 'Brocade $\mathrm{Red} /$ White Bicolour' were cut into small pieces $(2.0 \times 3.0 \mathrm{~mm})$, both white-veined and green-veined progenies, and then observed under a microscope (model SMZ-U; Nikon, Tokyo, Japan) equipped with a charge-coupled device digital camera (Optronics MicroFire $\AA$ True Color Firewire Digital CCD Camera; Meyer Instruments, Houston, TX). Samples of these whiteveined and green-veined leaf pieces $(2.0 \times 3.0 \mathrm{~mm})$ were subdivided and fixed in $2.5 \%$ glutaraldehyde in $0.1 \mathrm{M}$ phosphate buffer $(\mathrm{pH} \mathrm{7.3)}$ for $6 \mathrm{~h}$ and then postfixed in buffered $1 \%$ osmium tetroxide overnight at room temperature. After dehydration through an ethanol series, these materials were embedded in Spurr's resin (Spurr, 1969). For optical microscopic observations, the semi-thin sections were cut with a microtome (Ultracut R; Leica, Wetzlar, Germany) and stained with 1\% toluidine blue O. Photographs were obtained using digital cameras (Optiphot2; Nikon; and DMC-G1; Panasonic, Tokyo, Japan).

To fit the area of the white vein portion, a portable photosynthesis system (LI-6400; LI-COR, Lincoln, NE) equipped with a $0.5-\times 2-\mathrm{cm}$ leaf chamber was used to measure the net photosynthetic rate, stomatal conductance, intercellular carbon dioxide

Table 1. Segregation of leaf vein color of progeny of gloxinia crosses.

\begin{tabular}{|c|c|c|c|c|c|}
\hline \multirow[b]{2}{*}{ Cross (no. of crosses) ${ }^{z}$} & \multicolumn{2}{|c|}{ Leaf vein } & \multirow[b]{2}{*}{ Test ratio } & \multirow[b]{2}{*}{$\chi^{2}$} & \multirow[b]{2}{*}{$P$} \\
\hline & White & Green & & & \\
\hline $\mathrm{SS} \otimes(1)$ & 120 & 0 & $1: 0$ & 0 & 1 \\
\hline MultiBells Blue × SS (3) & 120 & 0 & $1: 0$ & 0 & 1 \\
\hline MultiBells Cherry $\times$ SS (4) & 120 & 0 & $1: 0$ & 0 & 1 \\
\hline MultiBells White $\times$ SS $(5)$ & 93 & 0 & $1: 0$ & 0 & 1 \\
\hline Diego Pink $\times$ MultiBells Blue $(8)$ & 120 & 0 & $1: 0$ & 0 & 1 \\
\hline ALVDT $\otimes(9)$ & 0 & 120 & $0: 1$ & 0 & 1 \\
\hline MultiBells White $\otimes(10)$ & 0 & 60 & $0: 1$ & 0 & 1 \\
\hline Espirito Santo $\otimes(11)$ & 0 & 112 & $0: 1$ & 0 & 1 \\
\hline Avanti Peach Rose $\otimes(12)$ & 0 & 64 & $0: 1$ & 0 & 1 \\
\hline Avanti Scarlet $\times$ Espirito Santo (17) & 0 & 120 & $0: 1$ & 0 & 1 \\
\hline Avanti Blue $\times$ ALVDT & 0 & 120 & $0: 1$ & 0 & 1 \\
\hline $\mathrm{ALVDT} \times \mathrm{BRWB}(19)$ & 0 & 109 & $0: 1$ & 0 & 1 \\
\hline Avanti Peach Rose $\times$ BRWB $(20)$ & 0 & 120 & $0: 1$ & 0 & 1 \\
\hline Avanti Scarlet $\times$ Brocade Purple (21) & 0 & 120 & $0: 1$ & 0 & 1 \\
\hline EPST $\times$ Brocade Red $(22)$ & 0 & 120 & $0: 1$ & 0 & 1 \\
\hline Brocade Purple $\times$ BRWB (23) & 0 & 120 & $0: 1$ & 0 & 1 \\
\hline$\left(\mathrm{SS} \times \mathrm{BRWB} \mathrm{F}_{1}\right) \otimes(24)$ & 89 & 26 & $3: 1$ & 0.55 & 0.35 \\
\hline$\left(\right.$ Diego Pink $\times$ MultiBells Blue $\left.F_{1}\right) \otimes(25)$ & 108 & 29 & $3: 1$ & 1.07 & 0.30 \\
\hline
\end{tabular}

${ }^{\mathrm{z}}$ ALVDT $=$ Avanti Light Violet/Dark Throat; BRWB = Brocade Red/White Bicolour; BPWB = Brocade Purple/White Bicolour; EPST

$=$ Empress Purple Spotted Throat. 
Table 2. Joint segregation of leaf vein color and flower form of progeny of gloxinia crosses.

\begin{tabular}{|c|c|c|c|c|c|c|c|}
\hline \multirow[b]{2}{*}{ Crosses (no. of crosses) ${ }^{\mathrm{z}}$} & \multicolumn{4}{|c|}{ Vein color/flower form ${ }^{y}$} & \multirow[b]{2}{*}{ Test ratio } & \multirow[b]{2}{*}{$\chi^{2}$} & \multirow[b]{2}{*}{$P$} \\
\hline & $\mathrm{W} / \mathrm{D}$ & $\mathrm{G} / \mathrm{D}$ & $\mathrm{W} / \mathrm{S}$ & $\mathrm{G} / \mathrm{S}$ & & & \\
\hline $\mathrm{SS} \otimes(26)$ & 0 & 0 & 120 & 0 & $0: 0: 1: 0$ & 0 & 1 \\
\hline SS $\times$ MultiBells Blue (27) & 0 & 0 & 36 & 0 & $0: 0: 1: 0$ & 0 & 1 \\
\hline MultiBells White $\times$ SS $(28)$ & 0 & 0 & 43 & 0 & $0: 0: 1: 0$ & 0 & 1 \\
\hline MultiBells White $\times(29)$ & 0 & 0 & 0 & 58 & 0:0:0:1 & 0 & 1 \\
\hline Avanti Peach Rose $\otimes(30)$ & 0 & 0 & 0 & 64 & $0: 0: 0: 1$ & 0 & 1 \\
\hline Avanti Blue $\times$ ALVDT $(33)$ & 0 & 0 & 0 & 120 & $0: 0: 0: 1$ & 0 & 1 \\
\hline Avanti Scarlet $\times$ Espirito Santo (34) & 0 & 0 & 0 & 45 & 0:0:0:1 & 0 & 1 \\
\hline Brocade Red $\otimes(35)$ & 0 & 33 & 0 & 11 & $0: 3: 0: 1$ & 0 & 1 \\
\hline $\mathrm{BPWB} \otimes(36)$ & 0 & 23 & 0 & 11 & $0: 3: 0: 1$ & 0.98 & 0.32 \\
\hline Brocade Purple $\times$ BRWB $(37)$ & 0 & 69 & 0 & 27 & $0: 3: 0: 1$ & 0.47 & 0.50 \\
\hline Avanti Peach Rose $\times$ BRWB $(38)$ & 0 & 18 & 0 & 24 & $0: 1: 0: 1$ & 0.86 & 0.65 \\
\hline $\mathrm{SS} \times \mathrm{BRWB}(42)$ & 57 & 0 & 69 & 0 & $1: 0: 1: 0$ & 1.14 & 0.29 \\
\hline$\left(\mathrm{SS} \times \mathrm{BRWB} \mathrm{F}_{1}\right) \otimes(43)$ & 54 & 24 & 21 & 7 & $9: 3: 3: 1$ & 0.74 & 0.69 \\
\hline
\end{tabular}

${ }^{\mathrm{z}}$ ALVDT $=$ Avanti Light Violet/Dark Throat; BRWB $=$ Brocade Red/White Bicolour; BPWB = Brocade Purple/White Bicolour; EPST $=$ Empress Purple Spotted Throat.

${ }^{\mathrm{y}} \mathrm{W} / \mathrm{S}=$ white vein/single flower; $\mathrm{G} / \mathrm{S}=$ green vein/single flower; W/D = white vein/double flower; G/D = green vein/double flower.

concentration, and transpiration rate of 'SS'. White vein and green portions of the fully expanded leaves (leaf 2 from the apex) from six plants were sampled and inserted in the leaf chamber, separately. Three consecutive measurements were obtained from the same leaf. The carbon dioxide concentration entering the leaf chamber and the leaf temperature were 380 $\mu \mathrm{mol} \cdot \mathrm{mol}^{-1}$ and $25 \pm 0.2{ }^{\circ} \mathrm{C}$, respectively. The difference in photosynthetic parameters was separated by the $t$ test.

\section{Results and Discussion}

INHERITANCE OF VEIN COLOR, FLOWER FORM, AND FLORAL SYMMETRY. Self-pollinated white-veined 'SS' produced all whiteveined progeny [cross 1 (Table 1)]. All plants from crossing 'SS' with green-veined cultivars were white-veined (crosses 2-7), including reciprocal crosses with green-veined 'MultiBells Blue' (crosses 2 and 3). All plants of white-veined 'Diego Pink' crossed with 'MultiBells Blue' produced white-veined progeny (cross 8). Plants from self-pollinating (crosses 9-16) or crosspollinating (crosses 17-23) green-veined cultivars produced all green-veined progeny. The $\mathrm{F}_{2}$ generation derived from whiteveined 'SS' $\times$ green-veined 'Brocade Red/White Biolocr' (cross 24) and white-veined 'Diego Pink' $\times$ green-veined 'MultiBells Blue' (cross 25) showed vein color segregation in a ratio of 3:1 of white:green among the progenies $\left(\chi^{2}=0.55-1.07 ; P=\right.$ $0.30-0.35$ ). These results indicated that the vein color trait seems to be controlled by a single nuclear gene, and that the white vein trait is dominant over the green vein trait (Table 1). Similar examples of the inheritance of vein color or silver-grey stripes overlaying the leaf veins have been reported for aglaonema (Henny, 1986), caladium (Deng and Harbaugh, 2006), and dieffenbachia cultivars (Henny, 1983). We propose that the locus governing the vein colors in gloxinia be labeled as $V$, and $V^{w}$ and $V^{g}$ representing the alleles for white and green veins, respectively. The white-veined cultivars SS and Diego Pink both possess homozygous dominant alleles $\left(V^{w} V^{w}\right)$, whereas all green-veined cultivars carry homozygous recessive alleles $\left(V^{g} V^{g}\right)$. The progeny of 'SS' or 'Diego Pink' crossed with green-veined cultivars carry heterozygous alleles for the white vein trait $\left(V^{w} V^{g}\right)$.

Regardless of vein color, all plants produced single flowers from crossing single-flowered cultivars [crosses 26-34 (Table 2)]. All plants from crosses between green-veined cultivars were green-veined, regardless of the flower form [crosses 35-40 (Table 2)]. Progeny of self-pollination or crosses between double-flowered Brocade cultivars segregated into a ratio of 3:1 of double flower:single flower [crosses 35-37 $\left(\chi^{2}=0-0.98 ; P=0.32-1\right)$ ]. Progeny of single-flowered cultivars crossed with Brocade cultivars exhibited segregation in a ratio of 1:1 of double flower:single

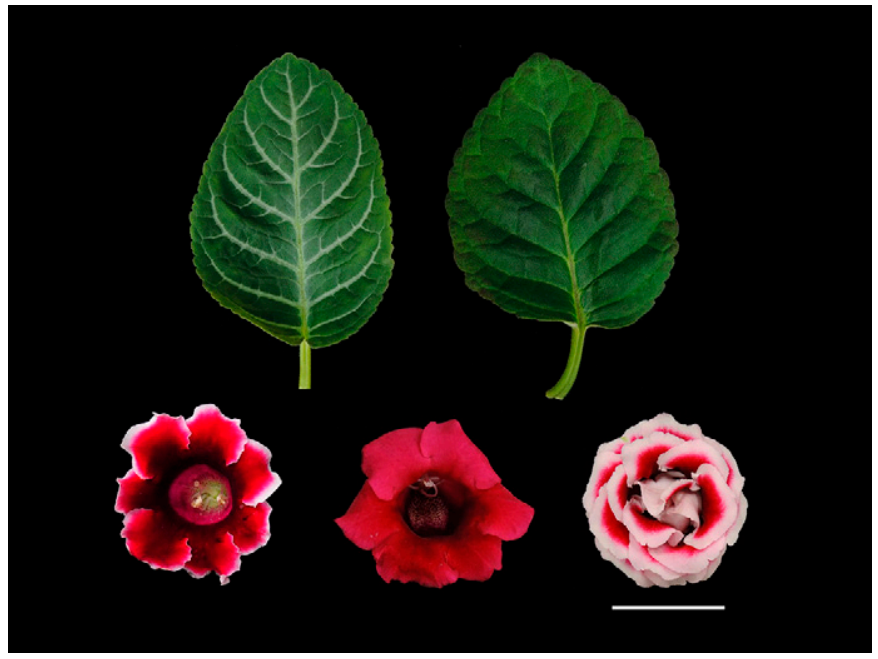

Fig. 1. Leaf vein color, floral symmetry, and flower form of gloxinia. The leaf with white lateral vein (top left) and leaf with green lateral veins top right). Single-flower/actinomorphy (bottom left), single-flower/zygomorphy (bottom middle), and double-flower/actinomorphy (bottom right). Bar $=5 \mathrm{~cm}$. 


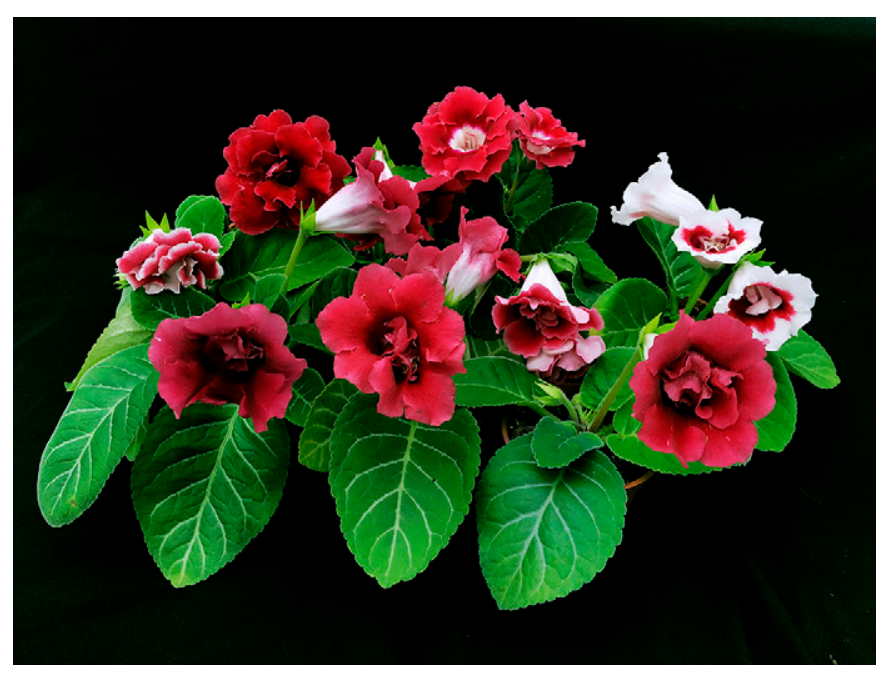

Fig. 2. Several white-veined and double-flowered gloxinia selected from the $\mathrm{F}_{2}$ generation of ' $\mathrm{SS}$ ' $\times$ 'Brocade Red/White Bicolour'.

flower [crosses 38-40 $\left.\left(\chi^{2}=0.08-4.16 ; P=0.04-0.78\right)\right]$. We propose that the locus governing the flower form in gloxinia should be labeled as $D$. The Brocade cultivars possess heterozygous dominant alleles $(D d)$, whereas all single-flowered cultivars carry homozygous recessive alleles $(d d)$. These results are consistent with those of Clayberg (1975), who reported that a single dominant gene leads to double flowers in gloxinia. Similar examples of dominant allele conditions for flower doubling have been reported for beach rose (Rosa rugosa), carnation (Dianthus caryophyllus), and petunia (Petunia $\times$ hybrida) (Gattolin et al., 2020).

Plants from ' $\mathrm{SS}$ ' $\times$ green-veined/double-flowered cultivars segregated into a ratio of 1:1 of white vein/double flower:white vein/single flower [crosses 41 and $42\left(\chi^{2}=0.80-1.14 ; P=\right.$ $0.29-0.37)$ ]. Plants of cross 43 segregated into a ratio of $9: 3: 3: 1$ of white vein/double flower:white vein/single flower:green vein/ double flower:green vein/single flower $\left(\chi^{2}=0.74 ; P=0.69\right)$.
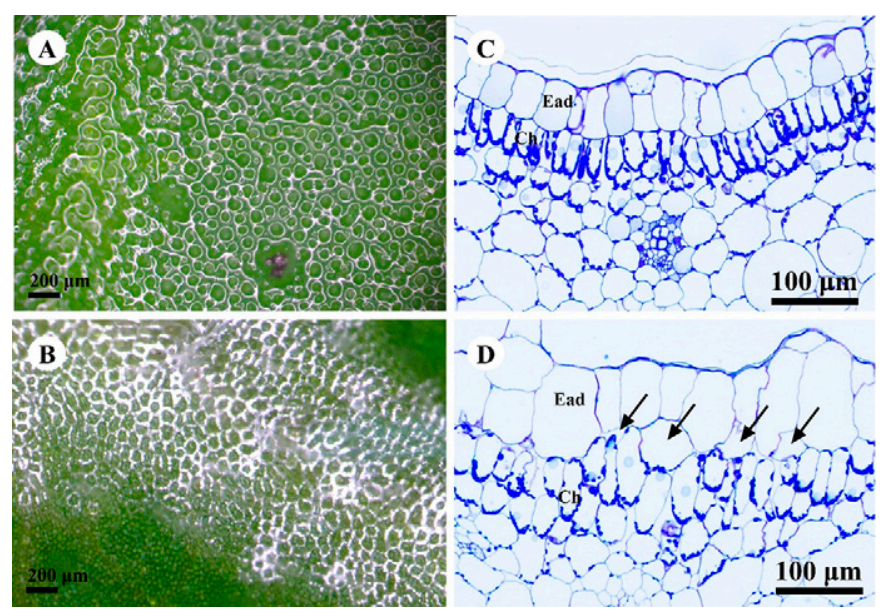

Fig. 3. Adaxial surface and cross-section of lateral vein areas of the $F_{2}$ progeny derived from crossing green-veined gloxinia 'Brocade Red/White Bicolour' and white-veined 'SS'. Green-veined progeny (A and $\mathbf{C}$ ) and whiteveined progeny $(\mathbf{B}$ and $\mathbf{D}) . \mathrm{Ch}=$ chlorenchyma; $\mathrm{Ead}=$ adaxial epidermis; arrows indicate air spaces.

The observed ratio supports that two independent loci control the two traits of vein color and flower form. New gloxinia progeny with homozygous white veins $\left(V^{\mathrm{w}} V^{\mathrm{w}}\right)$ and double flowers $(D D)$ were successfully developed from some of the $\mathrm{F}_{2}$ population (Fig. 2). Clayberg (1975) reported that double-flowered homozygotes have markedly more petals in gloxinia.

All plants of self-pollinating green-veined 'Espirito Santo' or 'Espirito Santo' crossed with green-veined 'Avanti Scarlet' were green-veined with zygomorphic flowers [crosses 44 and 45 (Table 3)], indicating 'Espirito Santo' is homozygous for floral symmetry $(C C)$. Progeny of self-pollinating green-veined 'MultiBells White' and a cross between 'MultiBells White' and white-veined ' $\mathrm{SS}$ ' segregated into a ratio of 3:1 of zygomorphic flower:actinomorphic flower (crosses 46 and 47), indicating that 'MultiBells White' and 'SS' are heterozygous $(C c)$. Progeny of

Table 3. Joint segregation of leaf vein color and floral symmetry of progeny of gloxinia crosses.

\begin{tabular}{|c|c|c|c|c|c|c|c|}
\hline \multirow[b]{2}{*}{ Crosses (no. of crosses) ${ }^{\mathrm{z}}$} & \multicolumn{4}{|c|}{ Vein color/floral symmetry ${ }^{\mathrm{y}}$} & \multirow[b]{2}{*}{ Test ratio } & \multirow[b]{2}{*}{$\chi^{2}$} & \multirow[b]{2}{*}{$P$} \\
\hline & $\mathrm{W} / \mathrm{Z}$ & $\mathrm{G} / \mathrm{Z}$ & $\mathrm{W} / \mathrm{A}$ & $\mathrm{G} / \mathrm{A}$ & & & \\
\hline Espirito Santo $\otimes(44)$ & 0 & 58 & 0 & 0 & $0: 1: 0: 0$ & 0 & 1 \\
\hline Avanti Scarlet $\times$ Espirito Santo $(45)$ & 0 & 45 & 0 & 0 & $0: 1: 0: 0$ & 0 & 1 \\
\hline MultiBells White $\otimes(46)$ & 0 & 38 & 0 & 20 & $0: 3: 0: 1$ & 2.78 & 0.095 \\
\hline MultiBells White × SS (47) & 33 & 0 & 10 & 0 & $3: 0: 1: 0$ & 0.07 & 0.79 \\
\hline SS $\times$ Brocade Purple $(48)$ & 50 & 0 & 51 & 0 & $1: 0: 1: 0$ & 0.01 & 0.92 \\
\hline Avanti Red with White Edge $\otimes(49)$ & 0 & 0 & 0 & 44 & $0: 0: 0: 1$ & 0 & 1 \\
\hline Avanti Peach Rose $\otimes(50)$ & 0 & 0 & 0 & 64 & $0: 0: 0: 1$ & 0 & 1 \\
\hline $\operatorname{ALVDT} \times \operatorname{BRWB}(51)$ & 0 & 0 & 0 & 109 & $0: 0: 0: 1$ & 0 & 1 \\
\hline Avanti Peach Rose $\times$ BRWB (52) & 0 & 0 & 0 & 42 & $0: 0: 0: 1$ & 0 & 1 \\
\hline Avanti Blue $\times$ ALVDT $(53)$ & 0 & 0 & 0 & 119 & $0: 0: 0: 1$ & 0 & 1 \\
\hline Avanti Scarlet $\times$ Brocade Purple $(54)$ & 0 & 0 & 0 & 96 & $0: 0: 0: 1$ & 0 & 1 \\
\hline EPST $\times$ Brocade Red $(55)$ & 0 & 0 & 0 & 103 & $0: 0: 0: 1$ & 0 & 1 \\
\hline Brocade Purple $\times$ BRWB (56) & 0 & 0 & 0 & 96 & $0: 0: 0: 1$ & 0 & 1 \\
\hline Brocade Red $\otimes(57)$ & 0 & 0 & 0 & 44 & $0: 0: 0: 1$ & 0 & 1 \\
\hline $\mathrm{BPWB} \otimes(58)$ & 0 & 0 & 0 & 34 & $0: 0: 0: 1$ & 0 & 1 \\
\hline$\left(\mathrm{SS} \times \mathrm{BRWB} \mathrm{F}_{1}\right) \otimes(59)$ & 57 & 18 & 23 & 8 & $9: 3: 3: 1$ & 0.48 & 0.78 \\
\hline
\end{tabular}

${ }^{\mathrm{z}}$ ALVDT $=$ Avanti Light Violet/Dark Throat; BRWB = Brocade Red/White Bicolour; BPWB = Brocade Purple/White Bicolour; EPST $=$ Empress Purple Spotted Throat.

${ }^{\mathrm{y}} \mathrm{W} / \mathrm{Z}=$ white vein/zygomorphic flower; $\mathrm{G} / \mathrm{Z}=$ green vein/zygomorphic flower; W/A = white vein/actinomorphic flower; $\mathrm{G} / \mathrm{A}=$ green vein/actinomorphic flower. 
Table 4. Photosynthetic characteristics of white and green leaf portions of gloxinia 'SS'.

\begin{tabular}{lcccc}
\hline Leaf portion & $\begin{array}{c}\text { Net photosynthetic rate } \\
{\left[\mathrm{CO}_{2}\left(\mu \mathrm{mol} \cdot \mathrm{m}^{-2} \cdot \mathrm{s}^{-1}\right)\right]}\end{array}$ & $\begin{array}{c}\text { Stomatal } \\
\text { conductance }\left(\mathrm{mol} \cdot \mathrm{m}^{-2} \cdot \mathrm{s}^{-1}\right)\end{array}$ & $\begin{array}{c}\text { Intercellular } \mathrm{CO}_{2} \\
\text { concn }\left(\mu \mathrm{mol}^{2} \cdot \mathrm{mol}^{-1}\right)\end{array}$ & $\begin{array}{c}\text { Transpiration rate } \\
\left(\mathrm{mmol}^{-1} \mathrm{~m}^{-2} \cdot \mathrm{s}^{-1}\right)\end{array}$ \\
\hline White & 5.94 & 0.073 & 251.3 \\
Green & 5.67 & 0.072 & 256.9 & 1.13 \\
Significance $(t$ test $)$ & $\mathrm{NS}$ & $\mathrm{NS}$ & $\mathrm{NS}$ & 1.12 \\
\hline
\end{tabular}

NS, nonsignificant.

'SS' crossed with green-veined 'Brocade Purple' segregated into a ratio of 1:1 of zygomorphic flower:actinomorphic flower (cross 48), revealing that 'Brocade Purple' contains homozygous actinomorphic alleles $(c c)$. Plants from self-pollinating or cross-pollinating cultivars Avanti, Brocade, and Empress Purple Spotted Throat (all green-veined) had a green vein and actinomorphic flowers (crosses 49-58). These results are consistent with those of previous reports indicating that actinomorphic flora is controlled by a recessive gene, whereas a single dominant gene expressed in the homozygous or heterozygous state resulted in zygomorphic flora (Clayberg, 1975; Hsu et al., 2017). The $F_{2}$ progenies derived from white-veined ' $\mathrm{SS}$ ' $\times$ green-veined 'Brocade Red/White Bicolour' segregated into a ratio of 9:3:3:1 of white vein/zygomorphic flower:green vein/zygomorphic flower:white vein/actinomorphic flower:green vein/actinomorphic flower [cross $59\left(\chi^{2}=0.48 ; P=0.78\right)$ ]. The observed ratio indicates that two independent loci control the two traits of vein color and floral symmetry. Similar examples of independent inheritance of vein color and leaf shape have been reported for caladium (Deng and Harbaugh, 2006) and growth habit and flower form for periwinkle [Catharanthus roseus (Lin et al., 2018)].

STRUCTURAL DIFFERENCE BETWEEN THE GREEN AND WHITE LEAF VEIN AREAS. A magnified image of the adaxial leaf epidermis showed that the white areas reflected much whiter light than the green areas (Fig. 3A and B). In the green leaf vein areas, the chlorenchyma cells tightly connected to the adaxial epidermal cells (Fig. 3C). In contrast, air spaces were observed between the adaxial epidermal cells and chlorenchyma cells in the white vein areas (Fig. 3D). These results indicated that the white vein of gloxinia was not caused by chlorophyll deficiency; it was caused by air spaces between the upper epidermis and the mesophyll cells. Similar examples of structural variegation have been reported for A. nitidum (Fooshee and Henny, 1990) and variegated begonias, including $B$. chlorosticta, B. diadema, B. formosana, $B$. hemsleyana, B. pustulata, B. rex, and B. versicolor (Sheue et al., 2012; Zhang et al., 2009). Sheue et al. (2012) explained the mechanism of the air space type of variegation according to Snell's law. When incident light obliquely encounters a cell-air interface, the interface of the adaxial epidermis and the air spaces reflects light, resulting in the lighter leaf color of this area. In green areas, incident light at various angels is transmitted between epidermis cells and the adjacent chlorochyma without reflection at the interface.

COMPARISON OF PHOTOSYNTHETIC PARAMETERS OF GREEN AND WHITE LEAF VEIN AREAS. The net photosynthetic rate, stomatal conductance, intercellular carbon dioxide concentration, and transpiration rate did not differ between the white and green areas of white-veined 'SS' leaves (Table 4). Minimal loss of function with variegation caused by the air space type has been documented for leaves of variegated Begonia species, including B. formosana, B. diadema, and B. pustulata (Sheue et al., 2012) based on the maximum quantum yield of photosystem II.

\section{Conclusions}

Results of this study showed that the white vein trait of gloxinia was controlled by a single dominant nuclear gene. The locus controlling the white/green leaf vein color is inherited independent of the loci controlling flower form or floral symmetry. A summary of proposed genotypes for all these cultivars is shown in Table 5. The mechanism of the white leaf vein trait of gloxinia is the air space type. We observed that plants with white veins

Table 5. Phenotype and proposed genotypes of gloxinia cultivars based on the progeny tests.

\begin{tabular}{|c|c|c|c|c|c|c|}
\hline Cultivar & \multicolumn{2}{|c|}{ Leaf vein color } & \multicolumn{2}{|c|}{ Flower form } & \multicolumn{2}{|c|}{ Floral symmetry } \\
\hline Avanti Blue & Green & $V^{g} V^{g}$ & Single & $d d$ & Actinomorphic & $c c$ \\
\hline Avanti Peach Rose & Green & $V^{g} V^{g}$ & Single & $d d$ & Actinomorphic & $c c$ \\
\hline Avanti Red with White Edge & Green & $V^{g} V^{g}$ & Single & $d d$ & Actinomorphic & $c c$ \\
\hline Avanti Scarlet & Green & $V^{g} V^{g}$ & Single & $d d$ & Actinomorphic & $c c$ \\
\hline Brocade Red & Green & $V^{g} V^{g}$ & Double & $D d$ & Actinomorphic & $c c$ \\
\hline Brocade Red/White Bicolour & Green & $V^{g} V^{g}$ & Double & $D d$ & Actinomorphic & $c c$ \\
\hline Empress Purple Spotted Throat & Green & $V^{g} V^{g}$ & Single & $d d$ & Actinomorphic & $c c$ \\
\hline Espirito Santo & Green & $V^{g} V^{g}$ & Single & $d d$ & Zygomorphic & $C C$ \\
\hline Multibells Blue & Green & $V^{g} V^{g}$ & Single & $d d$ & Zygomorphic & $C_{-}$ \\
\hline
\end{tabular}


grew as vigorously as those with green veins, as supported by the similar photosynthetic rates of white and green leaf portions. The newly developed double-flowered gloxinia progeny with white veins could lead to new cultivars that have even greater market appeal.

\section{Literature Cited}

Aluru, M.R., H. Bae, D. Wu, and S.R. Rodermel. 2001. The arabidopsis immutans mutation affects plastid differentiation and the morphogenesis of white and green sectors in variegated plants. Plant Physiol. 127:67-77.

Clayberg, C.D. 1975. Genetics of corolla traits in Gloxinia. J. Hered. 66:10-12.

Deng, Z. and B.K. Harbaugh. 2006. Independent inheritance of leaf shape and main vein color in Caladium. J. Amer. Soc. Hort. Sci. 131:53-58.

Fooshee, C.C. and R.J. Henny. 1990. Chlorophyll levels and anatomy of variegated and nonvariegated areas of Aglaonema nitidum leaves. Proc. Florida State Hort. Soc. 103:170-172.

Gattolin, S., M. Cirilli, S. Chessa, A. Stella, D. Bassi, and L. Rossini. 2020. Mutations in orthologous PETALOSA TOE-type genes cause a dominant double-flower phenotype in phylogenetically distant eudicots. J. Expt. Bot. 71:2585-2595.

Hara, N. 1957. Study of the variegated leaves, with special reference to those caused by spaces. Jpn. J. Bot. 16:86-101.

Henny, R.J. 1983. Inheritance of the white foliar midrib in Dieffenbachia and its linkage with the gene for foliar variegation. J. Hered. 74:483-484.

Henny, R.J. 1986. Single locus, multiallelic inheritance of foliar variegation in Aglaonema. J. Hered. 77:214-215.

Henny, R.J. and J. Chen. 2010. Cultivar development of ornamental foliage plants. Plant Breed. Rev. 23:245-290.
Hsu, H.C., C.N. Wang, C.H. Liang, C.C. Wang, and Y.F. Kuo. 2017. Association between petal form variation and CYC2-like genotype in a hybrid line of Sinningia speciosa. Front. Plant Sci. 8:558-570.

Hughes, N.M., K.L. Carpenter, T.S. Keidel, C.N. Miller, M.N. Waters, and W.K. Smith. 2014. Photosynthetic costs and benefits of abaxial versus adaxial anthocyanins in Colocasia esculenta 'Mojito'. Planta 240:971-981.

Lin, H.K., T.Y. Wei, C.M. Chen, and D.M. Yeh. 2018. Relationship between phloem fiber and trailing habit, and independent inheritance of growth habit and flower form in periwinkle. J. Amer. Soc. Hort. Sci. 143:67-71.

Pao, S.H., J.W. Liu, J.Y. Yang, P. Chesson, and C.R. Sheue. 2020. Uncovering the mechanisms of novel foliar variegation patterns caused by structures and pigments. Taiwania 65:74-80.

Shalit, P. 2000. Breeding gesneriads, p. 155-173. In: D.J. Callaway and M.B. Callaway (eds.). Breeding ornamental plants. Timber Press, Portland, OR.

Sheue, C.R., S.H. Pao, L.F. Chien, P. Chesson, and C.I. Peng. 2012. Natural foliar variegation without costs? The case of Begonia. Ann. Bot. 109:1065-1074.

Spurr, A.R. 1969. A low-viscosity epoxy resin embedding medium for electron microscopy. J. Ultrastructure Res. 26:31-43.

U.S. Department of Agriculture. 2021. National Agricultural Statistics Services. U.S. Dept. of Agr., Washington. 14 Jan. 2021. <https:// quickstats.nass.usda.gov/>.

Wang, R., J. Zhao, M. Jia, N. Xu, S. Liang, J. Shao, Y. Qi, X. Liu, L. An, and F. Yu. 2018. Balance between cytosolic and chloroplast translation affects leaf variegation. Plant Physiol. 176:804-818.

Zaitlin, D. 2012. Intraspecific diversity in Sinningia speciosa (Gesneriaceae: Sinningieae), and possible origins of the cultivated florist's gloxinia. AoB Plants 2012:pls039.

Zhang, Y., T. Hayashi, M. Hosokawa, S. Yazawa, and Y. Li. 2009. Metallic lustre and the optical mechanism generated from the leaf surface of Begonia rex Putz. Scientia Hort. 121:213-217. 